\title{
STRUCTURE-SCALE LEVELS OF CAST IRON ROLLS PLASMA HARDENING
}

\author{
Gromov V.E. ${ }^{1}$, Ivanov Yu.F. ${ }^{2,3}$, Konovalov S.V. ${ }^{1}$, Feng Ye. ${ }^{4}$, Kosinov D.A. ${ }^{1}$ \\ ${ }^{1}$ Siberian State Industrial University, Novokuznetsk, Russia \\ ${ }^{2}$ Institute of High Current Electronics SB RAS, Tomsk, Russia \\ ${ }^{3}$ Research Tomsk Polytechnic University, Tomsk, Russia \\ ${ }^{4}$ State Key Laboratory for Advanced Metals and Materials, University of Science and Technology Beijing, Beijing, China
}

\begin{abstract}
Through methods of modern materials science it is shown that plasma hardening of cast iron rolls of a rolling mill causes the formation of layers the structure of which is characterized by the regular change of mechanical characteristics, phase composition and defect substructure of the material and realized at different structure-scale levels: macro (the sample as a whole), meso (the state of the grain-subgrain ensemble), micro (the state of the carbide and dislocation subsystems), nano (the state of the solid solution). It is established that $\alpha, \gamma$-phases, graphite and cementite are formed in cast iron rolls as a result of plasma hardening. The formation of nanocrystalline $\alpha$-phase grain structure (with crystallite size of $35-40 \mathrm{~nm}$ ) stabilized with 3-5 nm cementite particles is found in the surface layer. It is established that utilization of hardened cast iron rolls predictably changes the defect substructure and the phase composition of cast iron. The sources of far-ranging stress fields were identified which are created in a cast iron roll as a result of plasma treatment and further operation. It is shown that the largest stress fields are created in the surface layer in the structure of nanocrystalline ferrite grains. Application of the plasma surface hardening technique led to an increased wear resistance in cast iron rolls. The evolution of the structure-phase states and the defect substructure in the surface layer of cast iron rolls was analyzed in the case of large diameter rebars production.
\end{abstract}

Keywords: Structure, phase composition, cast iron rolls, plasma hardening

\section{Introduction}

The development of technologies of hardening, as well as providing a desired combination between strength and plasticity of the materials requires the understanding of the nature of the applied processes. The clarification of the physical mechanisms of the formation and the evolution of structure and phase states is one of the most important problems of modern solid state physics, as it is in the basis of the development and the establishment of effective ways of the service characteristics improvement $[1,2]$.

An important problem determining to a great extent the performance of the mills is to increase the wear resistance of the cast-iron rolls. As one of its solutions is plasma hardening of the working surface of the rolls grooves. The process of hardening consists in high-temperature heating of surface area by plasma flow (anode spot) and its intensive cooling with a rate providing quenching structures. At the same time the roll toughness can increase by $\sim 60 \%[3,4]$.

The solution of practical tasks is impossible without understanding of the nature of the process of formation and the evolution of structure-phase states in steels and alloys in the conditions of external energy and deformation influences.

(C) Gromov V.E., Ivanov Yu.F., Konovalov S.V., Feng Ye, Kosinov D.A., 2016
The aim of this research work is to establish at different scaled levels the nature and regularities of the structure-phase states, the defect substructure, fracture surface of cast-iron rolls formation in the condition of plasma hardening and the analysis of their evolution in thermo-mechanically rolling of hardened reinforcement in different conditions.

\section{Material and the methods of research}

Cast rolls of about $500 \mathrm{~mm}$ in diameter made from cast iron brand SSHHNF were used as the research material. The composition is $\mathrm{C}=3.75 \%$, $\mathrm{Si}=1.52 \%, \quad \mathrm{Mn}=0.57 \%, \quad \mathrm{~S}=0.02 \%, \quad \mathrm{P}=0.15 \%$, $\mathrm{Cr}=0.35 \%, \mathrm{Ni}=1.51 \%, \mathrm{~V}=0.13 \%$ (weight percents).

The plasma treatment was carried out by plasmatron of a direct and (or) an indirect action. Plasma jet was produced by blowing into the electric arc stirred between the electrodes, the orifice, and the gas-dynamic compression in a channel-cooled nozzle passage. At the same time the plasma can either burn directly between the cathode and the anodeproduct (direct action) or burn between the electrode-cathode and the electrode-anode (indirect action). The processing of the grooves is produced by the excreted from the plasmatron torch.

After the surface patch is heated using the plasma arc it is rapidly cooled on the mass of the roll to obtain the hardening structures. The treatment 
scheme was set by the formation of circular tracks during the rotation of the roll. The velocity of displacement and the arc power are adjusted to obtain a heating temperature above the point $\mathrm{Ac}_{1}$ and below the melting temperature of the surface [3,4].

The main parameters of plasma hardening are: radiation power $\mathrm{P}$, diameter of active spot; velocity of displacement of the details, power density q. The parameters of plasma treatment were calculated: plasma arc power, active area of the arc spot, the heat flux density, the time of active spot hardening, hardening temperature, zone hardening depth.

The process of plasma hardening of roll grooves is shown in Fig.1. It was realized with the technical characteristics: arc power $-40 \mathrm{~kW}$, arc current $250 \mathrm{~A}$, arc voltage $-180 \mathrm{~V}$, efficiency $-180 \mathrm{~m} \mathrm{~min}^{-}$ ${ }^{1}$, pressure of plasma producing gas $-0.6 \mathrm{MPa}$, consumption of plasma producing gas $-5 \mathrm{~m}^{3}$ hour $^{-1}$, nozzle diameter $-1.2 \mathrm{~cm}$.

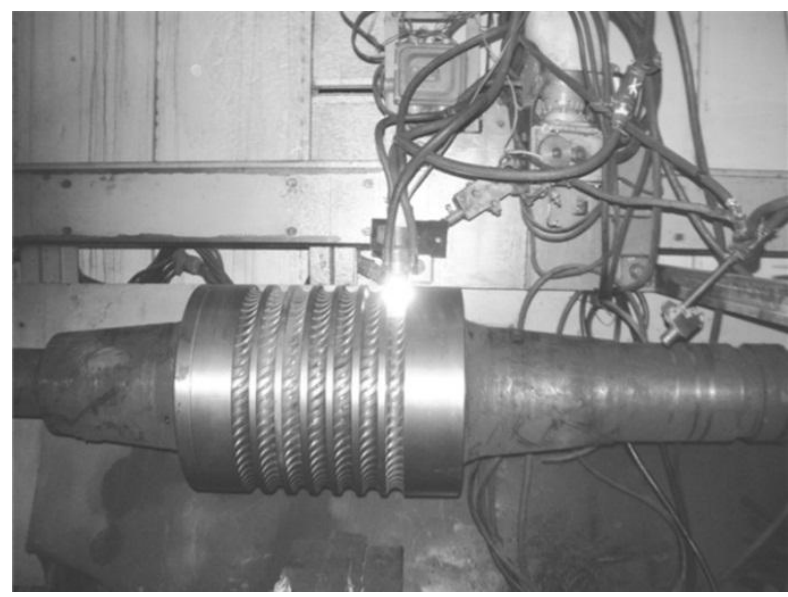

Fig. 1. The process of roll grooves plasma hardening

The results of industrial tests are presented in Table 1.

Table 1

Hardening and industrial tests of rolls

\begin{tabular}{|c|c|c|c|c|c|c|c|c|}
\hline \multirow{2}{*}{$\begin{array}{l}\text { № } \\
\text { № } \\
\text { п/П }\end{array}$} & \multirow{2}{*}{$\begin{array}{c}\text { Diame- } \\
\text { ter of } \\
\text { rolls, } \\
\mathrm{mm}\end{array}$} & \multicolumn{3}{|c|}{$\begin{array}{c}\text { Regime of treat- } \\
\text { ment }\end{array}$} & \multirow[b]{2}{*}{$\begin{array}{l}\text { Rolled } \\
\text { metal, } t\end{array}$} & \multicolumn{2}{|c|}{$\begin{array}{l}\text { Specific wear, } \\
\mathrm{mm}(100 \mathrm{t})^{-1}\end{array}$} & \multirow{2}{*}{$\begin{array}{c}\text { Increase of } \\
\text { the regula- } \\
\text { tory re- } \\
\text { sistance, } \\
\%\end{array}$} \\
\hline & & $\begin{array}{l}\text { noz- } \\
\text { zle, } \\
\mathrm{cm}\end{array}$ & I, A & \begin{tabular}{|c|}
$\mathrm{V}$ \\
$\mathrm{cms}^{-}$ \\
1
\end{tabular} & & $\begin{array}{l}\text { not } \\
\text { hard- } \\
\text { ened }\end{array}$ & & \\
\hline 1 & & 1.2 & 130 & 2.0 & & 0.075 & & +18 \\
\hline 2 & & & 150 & \begin{tabular}{|l|}
1.7 \\
\end{tabular} & & 0.175 & 0.08 & \\
\hline 3 & 505 & 1.2 & 150 & 1.5 & $10<0$ & 0.175 & 0.08 & +80 \\
\hline
\end{tabular}

The groove can be hardened after a single pass, which allows to exclude the zones of tempering with reduced mechanical properties and determined the maximum hardening in the areas of the most intense wear (in the extreme points of the vertical diameter of the groove).

The investigation of the structure was carried out on an optical microscope Axiovert 40MAT and an electron microscope EM-125. To identify the phases the diffraction analysis was applied with the use of a dark-field technique and the subsequent indexing of micro electron-diffraction pattern. The scalar density of dislocations was measured by the linear-intercept method adjusted for the invisibility of dislocations in the micrographs [5-7].

\section{Results and discussions}

The tests of plasma-hardened rolls at hot rolling of a large diameter reinforcement $(32-40 \mathrm{~mm})$ showed a significant increase in wear resistance (Table 1). Such an increase in service properties of the rolls is due to the formation of structural-phase states at plasma processing at different scale levels [8-10].

In the initial state and after the operation on the mill the working surface layer of the roll body contains perlite, cementite, and globular graphite. The formation of the hardened layer consisting of a melting zone with a hardness of 1000-1100 HV and fine austenite structure and cementite and the heat-affected zones with the hardness of 400-990 HV and with the structure of martensite, residual austenite and graphite.

The depth of the hardened layer varies from 0.3 to $2.5 \mathrm{~mm}$. The microhardness distribution along the cross section of the roll treated according to regime: $\mathrm{I}=150 \mathrm{~A}$, $\mathrm{V}=0.9 \mathrm{~cm} \mathrm{~s}^{-1}$, without melting is shown at Fig. 2 .

The modified surface, as compared with the cast one, is characterized by a reduced oxidation characteristic and high wear resistance, which are stored in the temperature range of the rolling service.

The main element of the macrostructure of the surface layer is graphite of a globular form, which is nonuniformly located in the thickness of a roll. There are almost no globules in the surface layer of a thickness about $50 \mu \mathrm{m}$, which indicates that they are dissolved in plasma processing of the material. In greater depths, the globules are found, their linear density increases with the removal from the processing surface. Globules of graphite have a certain structure, which explicitly manifests itself only in the surface layer of $~ 150$ $200 \mu \mathrm{m}$ thickness. In this layer the formation of circular-shaped areas of micron size around the globules of graphite is frequently observed. This occurs as a result of melting of the matrix around the globules of graphite and the subsequent rapid melting of the material. The thickness of the surface layer with a low volume fraction of globules of graphite after the operation increases and reaches about 1-2 mm. 
At the mesolevel the roll operation subjected to plasma treatment, is accompanied by the destruction of the surface layer forming fragments and chipping of the material in the contact zone of adjacent fragments. The layer, which is formed during the crystallization of the melt, has a strongly pronounced columnar structure. The operation of a plasma hardened roll on the rolling of a heat-strengthened reinforcement led to the transformation of the columnar structure with the formation of equiaxed crystallites, having a size of 5-8 $\mu \mathrm{m}$. The cupsof cleavage, having a size of $\sim 0.8-1 \mu \mathrm{m}$ are observed on the fracture.
At the microscale level electron diffraction microscopy revealed the formation of the structure consisting of an $\alpha$-phase, $\gamma$-phase, graphite and iron carbide (cementite) in the layer. These phases are distributed in the volume of the researched material in a natural manner; their relative content essentially depends on the depth of the analyzed layer.

Structurally free ferrite is presented in two morphological states - micron-sized grains with chaotic dislocation substructure with a scalar density of $3.2 \cdot 10^{10} \mathrm{~cm}^{-2}$ and nano-scale grains (Fig. 3).

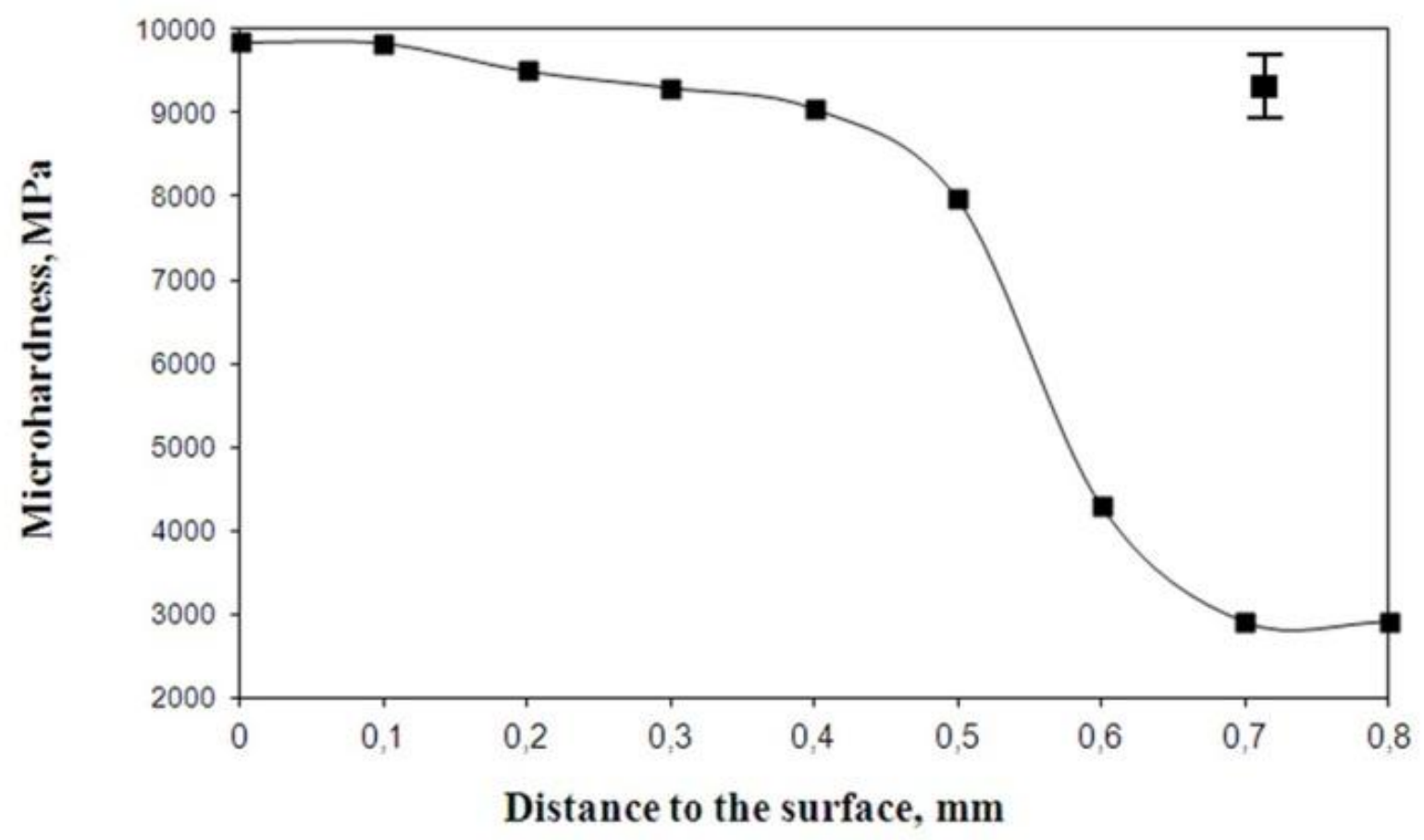

Fig. 2. Microhardness distribution along the cross section of the roll
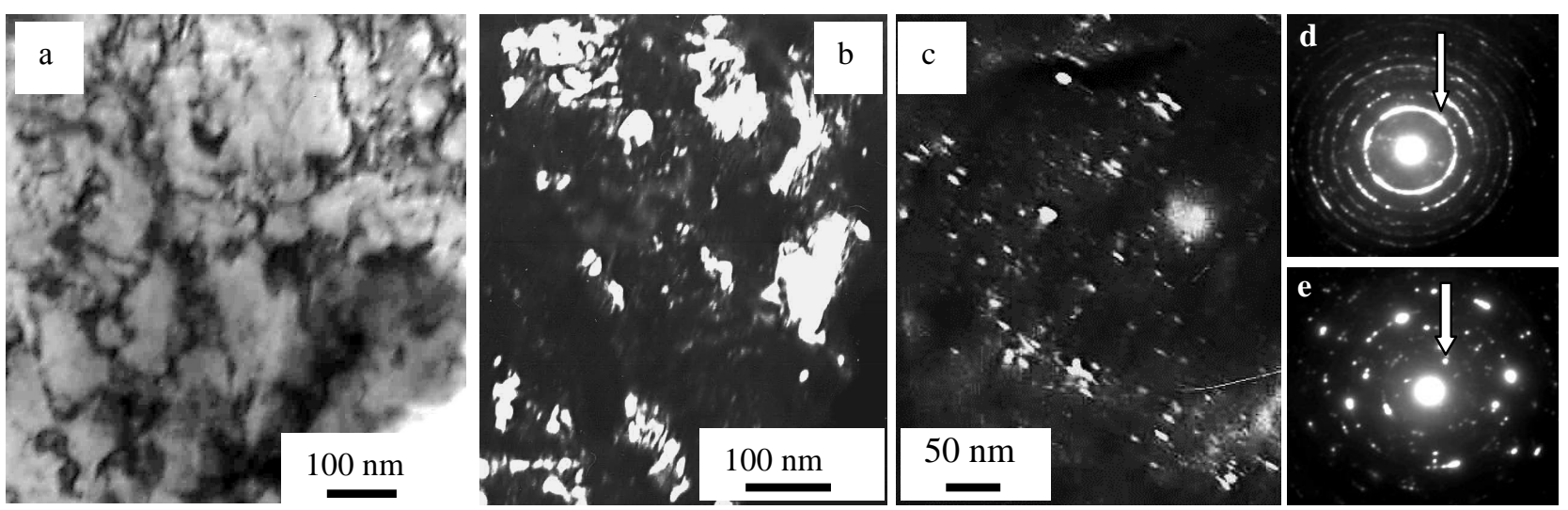

Fig. 3. Electron-microscope images of the structure of plasma-hardened cast iron (nanodimensional ferrite grain):

(a) light field; (b, d) dark fields obtained in [110]a-Fe and [101]Fe $\mathrm{C}_{3}$ reflexes;

(c, e) electron microdiffraction patterns (the arrow indicates the dark field reflex) 
Austenite has two morphologic types: scalar austenite grains with dislocation density of $3.6 \cdot 10^{10} \mathrm{~cm}^{-2}$ in terms of chaos and nets, and also the interlayer and the islands of various shapes and sizes which are presented in the structure of martensite or vice versa, are separated by a separately arranged crystals of martensite (all depends on the ratio of the volume fraction of austenite and martensite) with scalar density $\langle\rho\rangle=5 \cdot 10^{10} \mathrm{~cm}^{-2}$. Graphite is presented in the form of grains (globules) whose dimensions vary from units to tens of micrometers.

Cementite is presented in the form of individual grains (globules) of different shapes and sizes, as well as secondary and tertiary cementite. Granular cementite type usually has a dislocation substructure in the form of randomly distributed dislocations. The scalar dislocation density is relatively small $\langle\rho\rangle \sim 1 \cdot 10^{10} \mathrm{~cm}^{-2}$ (Table 2).

The solution of cementite and graphite grains leads to the formation of another type of structure, consisting of submicronic cementite particles, austenite threads, and ferrite crystals or grains (in some cases, pearlite grains) of submicron dimensions. Characteristic electron-microscope images of such structure are shown in Fig. 4.

Table 2

Morphological composition of plasma treated cast-iron, revealed by the methods of diffraction electron microscopy

\begin{tabular}{|c|c|}
\hline $\begin{array}{l}\text { Distance from } \\
\text { the surface, } \mu \mathrm{m}\end{array}$ & Morphological composition \\
\hline 0.5 & layers of residual austenite, the grains of the structure free ferrite, packet and plate martensite, "autotempered" cementite (secondary) \\
\hline 50 & $\begin{array}{l}\text { grains and layers of residual austenite, the grains of structure free ferrite, packet and plate martensite, secondary ce- } \\
\text { mentite, grains of graphite }\end{array}$ \\
\hline 160 & $\begin{array}{l}\text { Grains and layers of residual austenite, the grains of the structure free ferrite, packet and plate martensite, globules of } \\
\text { primary cementite, cementite (secondary), grains of graphite }\end{array}$ \\
\hline 210 & $\begin{array}{l}\text { grains, islands and layers of residual austenite, the grain of the structure free ferrite, packet and plate martensite, grains } \\
\text { (globules) of primary cementite, «autotempered» cementite (secondary), grains of graphite }\end{array}$ \\
\hline 260 & $\begin{array}{l}\text { Layers of residual austenite, the grain of the structure free ferrite, packet and plate martensite, pearlite, globules of } \\
\text { primary cementite, secondary cementite, grains of graphite }\end{array}$ \\
\hline 1100 & the grains of the free structure ferrite, grains of pearlite, grains (globules) of primary cementite, grains of graphite \\
\hline
\end{tabular}
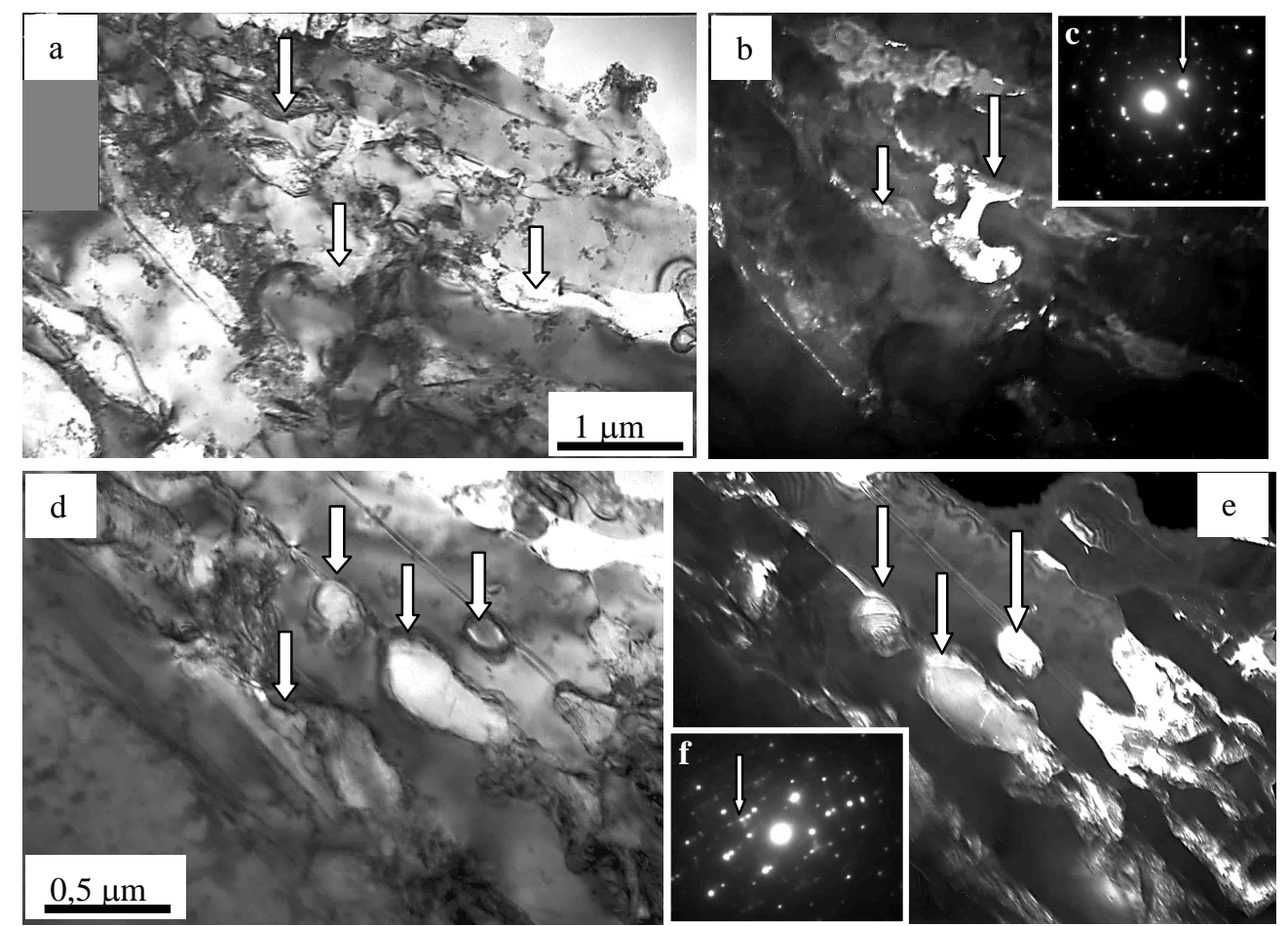

Fig. 4. Electron-microscope images of the structure of quenched cast iron: $(a, d)$ light field; $(b, e)$ dark fields obtained in [031] $\mathrm{Fe}_{3} \mathrm{C}$ and [122] $\mathrm{Fe}_{3} \mathrm{C}$ reflexes; (c, f) electron microdiffraction patterns corresponding to the light-field images (a, d). A thin arrow indicates the dark field reflex; broad arrows indicate cementite globules 
The structure-phase state of the layer at a depth of around $1100 \mu \mathrm{m}$ - i.e., a layer beyond the thermal influence zone - consists of plate and globular pearlite grains (plate pearlite predominates), pseudopearlite grains, graphite grains, cementite globules, and grains of structure-free ferrite, containing a small quantity of cementite nanoparticles. The layer at a depth of around $260 \mu \mathrm{m}$ (the thermal influence zone) has a more diverse structure, with the following phases: residual austenite, plate and packet martensite, plate and globular pearlite, and cementite and graphite globules. In most cases, pearlite is at the stage of thermal disintegration. The layer at a depth of $210 \mu \mathrm{m}$ (the boundary of the melt and the thermalinfluence zone) is formed as a result of rapid requenching. The basic structural components are austenite and martensite. Insoluble cementite and graphite globules are present. No pearlite grains are seen. The brevity of heat treatment prevents equalizing diffusion of the carbon, and consequently a highly non-uniform structure is formed, containing grains of structure-free austenite; austenite grains containing cementite at the boundaries and within the body; austenite grains containing martensite crystals (from a few percent to tens of percent, by volume); and grains in which martensitic transformation is practically complete and the structure consists mainly of packet martensite, which is typical of low- and moderatecarbon steel. The layer at a depth of around $160 \mu \mathrm{m}$ (the layer formed from the melt) is characterized by partial solution of the cementite and graphite globules and the formation of a complex structure, containing, within a small volume, submicronic cementite particles, austenite residues, martensite crystals, or submicronic ferrite grains. Structurally, this layer is very nonuniform; in this respect, it is similar to the layer at a depth of $210 \mu \mathrm{m}$. A structure of similar phase and morphological composition is also formed in the layer at a depth of around $50 \mu \mathrm{m}$. The basic difference is that, in the $160 \mu \mathrm{m}$ layer, the primary-cementite globules are practically completely dissolved.

A distinctive structure is formed in the surface layer. The main components are $\alpha$-phase and cementite. The $\alpha$-phase grains form a nanocrystalline structure (Fig. 3), characterized by annular electron microdiffraction patterns; this indicates that the crystallites are small (Fig. 3, c).

Along the boundaries of the $\alpha$-phase particles there are cementite particles. Martensite crystals (mainly of packet morphology) form the second structural component of the surface layer. Along the boundaries of the martensite crystals, there is a cementite layer formed as a result of self-tempering of the quenched structure, as well as small $\alpha$-phase grains $(0.5-1 \mu \mathrm{m})$ and residual-austenite deposits. The chaotic scalar dislocation density is around $3.2 \cdot 10^{10} \mathrm{~cm}^{-2}$. No cementite or graphite globules are seen. Judging from the morphological and phase composition of the surface layer, we may assume significant carburization of the material, as a result of the vaporization of carbon atoms from the surface.

At the nanoscale level on the surface of the plasma treatment the formation of nano-scale structures (crystallite sizes of $35-40 \mathrm{~nm}$ ) on the base of $\alpha$-phase can be observed. The cementite particles were found out whose sizesare $\sim 3-5 \mathrm{~nm}$ at the crystal boundaries of $\alpha$-phase (Fig. 3).

Plasma treatment of rolls leads to the formation of long-range stress fields, the sources of which are intraphase and interphase boundaries (Fig. 5, 6).

The electron microscopic image of lamellar pearlite colonies is shown at Fig. 5. A series of bend extinction contours are formed at the cementiteferrite boundary.

An electron-microscope image of nanocrystalline ferrite grains formed in the surface layer on plasma treatment is shown in Fig. 6, a. It is evident that this structure contains many bend extinction contours of different morphology. However, they all begin and end at the grain boundaries. In most cases, the contour thickness is a minimum at the ferrite grain boundaries and smoothly increases on moving away from these boundaries.

The contour thickness $\mathrm{X}$ is plotted in Fig. 6, b on moving from one nanostructural grain to another. This motion is accompanied by undulatory variation in contour thickness, which is a minimum at the grain boundaries. Hence, the curvature and torsion of the ferrite lattice and the amplitude of the longrange stress fields in the ferrite grains will be greatest at the boundary of two grains and least within the grains. The long-range stress fields formed in the surface layer of the cast-iron roller when nanocrystalline grains are formed may be estimated [1113]. With maximum contour width $\mathrm{h}=33 \mathrm{~nm}$ at the center of the ferrite grain, the lattice curvature and torsion and the magnitude of the long-range stress field will be $\chi=52 \cdot 10^{2} \mathrm{rad} \mathrm{cm}^{-1}$ and $\sigma=957 \mathrm{MPa}$, respectively. At the boundary of the nanocrystalline grains, $\mathrm{h}=5 \mathrm{~nm}, \chi=34 \cdot 10^{3} \mathrm{rad} \mathrm{cm} \mathrm{cm}^{-1}$, and $\sigma=2450$ $\mathrm{MPa}$. Obviously, very large stress may lead to microcrack formation at the roll surface.

The analysis of the curvature-torsion of the crystal lattice $(\chi)$ and the long-range stress fields $\sigma$ is shown in Table 3. 

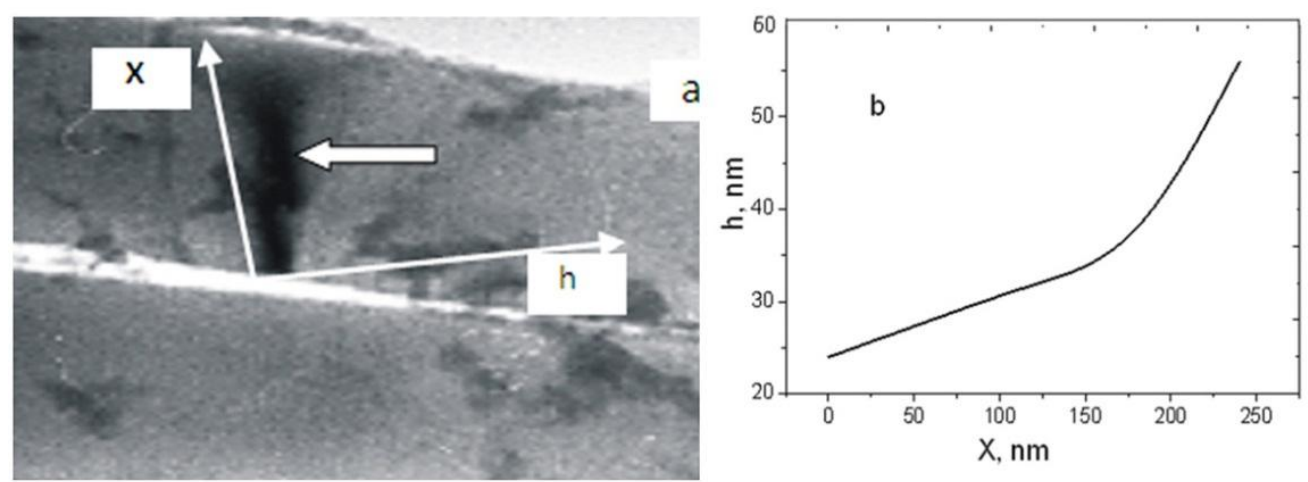

Fig. 5. Electron microscopic image of lamellar pearlite colonies (a) and the dependence of thickness of the bending extinction contour from the distance to the interface between cementite and ferrite plates (b). On (a) the arrow marks the extinction bending contour, indicating the curve-torsion of ferrite plate lattice
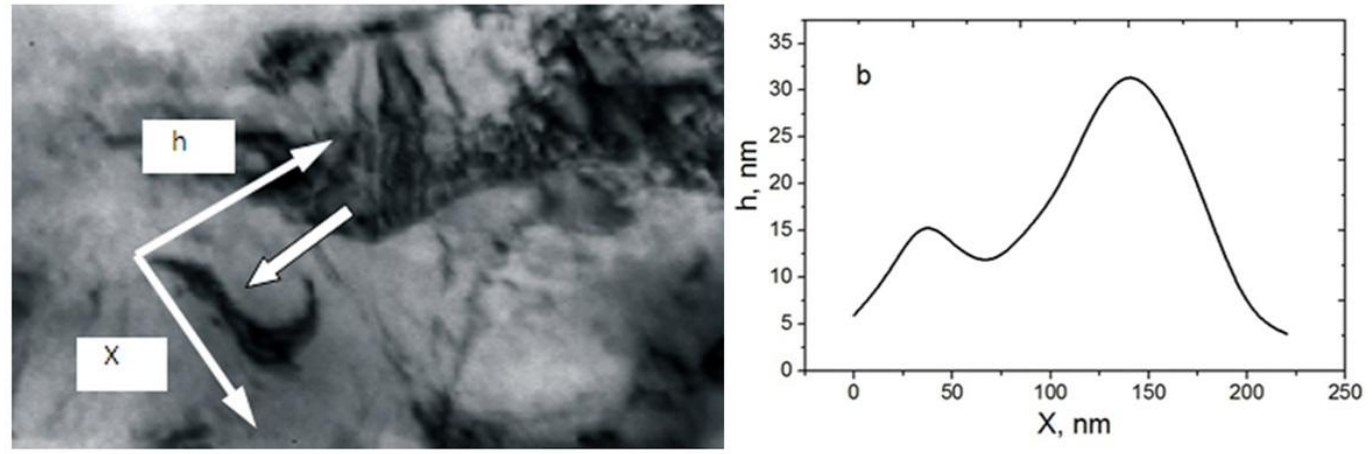

Fig. 6. Electron-microscope image of nanocrystalline ferrite grains formed in the surface layer of plasma-hardened cast iron (a) and dependence of the thickness of the bend extinction contour on the distance to the boundary of the nanocrystalline ferrite grains (b). The arrow in the microphotograph indicates the bend extinction contour, indicating bend and curvature of the ferrite lattice

Table 3

Curvature-torsion and long-range stress fields

\begin{tabular}{|l|c|c|c|c|c|c|}
\hline \multirow{2}{*}{ Structural elements } & \multicolumn{2}{|c|}{$\mathrm{h}, \mathrm{nm}$} & \multicolumn{2}{c|}{$\chi, 10^{2} \mathrm{rad} \mathrm{cm}^{-1}$} & \multicolumn{2}{c|}{$\sigma, \mathrm{MPa}$} \\
\cline { 2 - 8 } & $\mathrm{h}(\mathrm{min})$ & $\mathrm{h}(\mathrm{max})$ & $\chi(\min )$ & $\chi(\max )$ & $\sigma(\min )$ & $\sigma(\max )$ \\
\hline \multirow{2}{*}{ Grains of structure free ferrite } & 250 & 715 & 2,4 & $6,8 \cdot$ & 210 & 350 \\
& 50 & 230 & 3,5 & 7,5 & 245 & 360 \\
\hline \multirow{2}{*}{ Lamellar perlite } & 24 & 56 & 30,4 & 71 & 730 & 1120 \\
& 31 & 108 & 15,5 & 55 & 525 & 982 \\
\hline \multirow{2}{*}{ Nanosized ferrite grains } & 5 & 33 & 52 & 340 & 957 & 2450 \\
\hline
\end{tabular}

Notes: Numerator - after plasma hardening, denominator - after the service. $X$ - curvature-torsion of crystal lattice, $\sigma$ - long-range stress fields.

The service of a plasma hardened roll leads to a redistribution of long-range stress fields, however, the maximum stress level is stored in the structure of the surface layers, namely, in the structure of nano-sized grains of ferrite $-\sigma=1730 \mathrm{MPa}$, but their magnitude becomes slightly lower as compared to plasma hardened rolls $(\sigma=2450 \mathrm{MPa})$.

\section{Conclusion}

At different scaled levels (macro-, meso-, microand nano-) we defined the nature of the formation and changes in structure phase states, dislocation substructure of cast iron rolls at modern strengthening treatments that provide a significant increase of service characteristics at the subsequent operation.

Plasma strengthening treatment of rolls leads to the formation of the melting zone and the heat affected zone (macrolevel). The layer formed as a result of highspeed crystallization of melt has a columnar structure (mesolevel). The formed $\alpha$-phase, $\gamma$-phase, graphite and cementite are distributed in the volume of the researched material in a regular manner, their relative content and morphology strongly depend on the depth of the layer (microlevel). In the surface layer the formation of a nanocrystalline grain structure is revealed, which is based on $\alpha$-phase (the size of crystals is $35-40$ $\mathrm{nm}$ ), stabilized by cementite particles of $\sim 3-5 \mathrm{~nm}$ size (nanolevel). The maximum range of long-range stress 
fields $(\sigma=2450 \mathrm{MPa})$ is formed in the surface layer of nanoscale ferrite grains, the minimum $(\sigma=350 \mathrm{MPa})$ in a structure free ferrite grains.

The service of plasma strengthened rolls is accompanied by multiple regular changes of the defect substructure and phase composition. There is a significant ( in order) grinding of carbon inclusions, their dissolution, leading to the formation of an eutectoid structure.

\section{References}

1. Efimov O.Yu., Gromov V.E., Ivanov Yu.F. Formation of the structure, phase composition and the properties of steels and alloys in strengthening forming technologies. Novokuznetsk: Publishing house "Inter-Kuzbass", 2012, 345 p.

2. Efimov O.Yu. Structure phase states and the technology of the production of strengthened steel bars and cast iron rolls. Novokuznetsk: Publishing House JSC "Novokuznetsk Printing Plant", 2008, $300 \mathrm{p}$.

3. Efimov O.Yu., Yuryev A.B., Gromov V.E. Plasma hardening of high-carbon alloys: the physical nature and technology. Novokuznetsk: Publishing House JSC "Novokuznetsk Printing Plant", 2009, 220 p.

4. Gromov V.E., Efimov O.Yu., Kosterev V.B. Structure phase states and properties of hardened rolled steel products and cast iron rolls. Novokuznetsk: Printing house of SibSIU, 2011, 200 p.
5. Khirsh P., Khovi A., Nikolson R.I. Electron microscopy of thin crystals. Moscow: Mir, 1968, $574 \mathrm{p}$.

6. Endryus K., Dayson D., Kioun S. Electron diffraction patterns and their interpretation. Moscow: Mir, 1971, $256 \mathrm{p}$.

7. Chernyavskii K.S. Stereology in physical metallurgy. Moscow: Metallurgiya, 1977, $280 \mathrm{p}$.

8. Belov E.G., Efimov O.Yu., Ivanov Yu.F., Gromov V.E., Kolubaeva Yu.A. Evolution of the structural and phase states in hardened cast iron rolls: part 1. Steel in Translation, 2010, no. 4, pp. 322-324.

9. Gromov V.E., Ivanov Yu.F., Tang G., Efimov O.Yu. Formation and evolution of nanosized structure-phase states of cast iron during plasma hardening and subsequent operation. Advanced materials, 2011, no. 13, pp. 202-206.

10. Efimov O.Yu., Chinokalov V.Ya., Gromov V.E., Ivanov Yu.F., Konovalov S.V. Increase of resistance in cast iron rolls due to plasma treatment. Fundamental problems of modern materials science, 2011, no. 2, pp. 5-11.

11. Teplyakova L.A., Ignatenko L.N., Kasatkina N.F. et al Proc. Conf. "Plastic Deformation of Alloys: Structurally Inhomogeneous Materials". Tomsk: Tomsk State University, 1987, pp. 26-51.

12. Gromov V.E., Kozlov E.V., Bazaikin V.I. et al. The Physics and Mechanics of Drawing and Bulk Stamping. Moscow: Nedra, 1997, 290 p.

13. Koneva N.A., Lychagin D.V., Teplyakova L.A. et al. Experimental Investigation and Theoretical Description of Disclinations. Leningrad: Izd. FTI, 1984, pp. 161-164.

Материал поступил в редакцию 26.04.16.

INFORMATION ABOUT THE PAPER IN ENGLISH

DOI:10.18503/1995-2732-2016-14-2-69-75

\title{
СТРУКТУРНО-МАСШТАБНЫЕ УРОВНИ ПЛАЗМЕННОГО УПРОЧНЕНИЯ ЧУГУННЫХ ВАЛКОВ
}

\author{
Громов В.Е., Иванов Ю.Ф., Коновалов С.В., Фенг Ю., Косинов Д.А.
}

Аннотация. Методами современного физического материаловедения показано, что плазменное упрочнение валков прокатного стана приводит к формированию слоистой структуры, характеризующейся закономерным изменением механических характеристик, фазового состава, дефектной субструктуры материала и проявляющейся на различных структурномасштабных уровнях: макро- (образец в целом), мезо(состояние зеренно-субзеренного ансамбля), микро(состояние карбидной и дислокационной подсистем) и наноструктурном (состояние твердого раствора) уровнях. Установлено, что в результате плазменной обработки в чугунных валках формируются $\alpha$-фаза, $\gamma$-фаза, графит и карбид железа. В поверхностном слое обнаружено формирование нанокристаллической зеренной структуры на основе а-фазы (размер кристаллитов 3540 нм), стабилизированной частицами цементита раз- мером 3-5 нм. Установлено, что эксплуатация упрочненных валков сопровождается закономерным изменением дефектной субструктуры и фазового состава чугуна. Определены источники дальнодействующих полей напряжений, формирующихся в валке в результате плазменной обработки и последующей эксплуатации. Показано, что поля напряжений максимальной величины формируются в поверхностном слое в структуре нанокристаллических зерен феррита. В результате использования технологии плазменной поверхностной закалки повысилась износостойкость чугунных валков. Проанализирована эволюция структурно-фазовых состояний и дефектной субструктуры поверхностного слоя чугунных валков при прокатке арматуры большого диаметра.

Ключевые слова: структура, фазовый состав, чугунные валки, плазменное упрочнение.

Структурно-масштабные уровни плазменного упрочнения чугунных валков / Громов В.Е., Иванов Ю.Ф., Коновалов С.В., Фенг. Ю., Косинов Д.А. // Вестник Магнитогорского государственного технического университета им. Г.И. Носова. 2016. Т.14. №2. C. 69-75. doi:10.18503/1995-2732-2016-14-2-69-75

Gromov V.E., Ivanov Yu.F., Konovalov S.V., Feng Ye., Kosinov D.A. Structure-scale levels of cast iron rolls plasma hardening. Vestnik Magnitogorskogo Gosudarstvennogo Tekhnicheskogo Universiteta im. G.I. Nosova [Vestnik of Nosov Magnitogorsk State Technical University]. 2016, vol. 14, no. 2, pp. 69-75. doi:10.18503/1995-2732-2016-14-2-69-75 